\title{
"Constantemente derrubo lágrimas": o drama de uma liderança negra no cárcere do governo Vargas
}

\author{
Petrônio Domingues
}

\section{Introdução}

No dia 11 de fevereiro de 1936, um ofício do presídio político Maria Zélia, em São Paulo, foi enviado para Egas Botelho, superintendente da Delegacia de Ordem Política e Social (Deops), o principal órgão de repressão política do governo de Getúlio Vargas. O ofício descrevia as atividades políticas levadas a cabo por Isaltino Benedicto Veiga dos Santos uma das principais lideranças negras do país na década de 1930 - e, ao mesmo tempo, o acusava de comunista e subversivo:

Isaltino Benedicto Veiga dos Santos está, efetivamente, preso no Presídio Político [...]. Partidário da doutrina comunista, o paciente filiou-se à Aliança Nacional Libertadora e logo tratou de arregimentar todos os elementos de cor em torno daquele Partido, organizando, para melhor servir aos seus fins, a Federação dos Negros.

Mas não ficou nesse setor a sua atuação. Assinou também o manifesto da 'Frente Popular pela Liberdade', em companhia do general Miguel Costa e outros; freqüentava assiduamente reunióes de sindicatos, principalmente do Sindicato Unitivo dos Ferroviários da Central do Brasil, e redigia constantemente boletins subversivos, espalhados durante a noite, sub-repticiamente, nas ruas da Capital, principalmente nos bairros operários.

Era, enfim, um propagandista ativo do credo marxista, agitador, subversor da ordem - perigoso, portanto, à ordem pública e às instituições, e, em consequiência, mais que suspeito a esta Delegacia [de Ordem Política e Social], num momento de graves apreensões como o que atravessamos. ${ }^{1}$

Para entender o conteúdo do ofício produzido pela Deops, faz-se necessária uma breve contextualização histórica. Em 23 de novembro de 
1935, irrompeu-se a chamada "Intentona" Comunista. Superestimando a existência de um clima favorável à revolução socialista no país, o Partido Comunista do Brasil, auxiliado por agentes de Moscou, lançou-se numa tentativa malograda de tomada do poder. Desencadeada inicialmente em Natal, cidade que foi tomada pelos comunistas durante quatro dias, a "Intentona” foi estendida para quartéis de Recife e Rio de Janeiro. Esse estopim de insurreição nacional foi efêmero, sendo logo dominado pelas forças federais.

Após o levante comunista, o presidente da república, Getúlio Vargas, sepultou de vez a Constituição de 1934 e eliminou qualquer possibilidade de exercício da democracia representativa no país. Ele recrudesceu as medidas repressivas: decretou o estado de sítio e arrochou a Lei de Segurança Nacional. Todos os meios de comunicação foram censurados. O movimento operário foi debelado; os sindicatos, controlados. Os problemas que o governo enfrentava foram temporariamente escamoteados pela cortina de fumaça do patriotismo e da união nacional. Em 1936, foi criada a Comissão Nacional de Repressão ao Comunismo. ${ }^{2}$ Os escritores Jorge Amado, Rachel de Queiroz e Graciliano Ramos, o sociólogo Gilberto Freyre, o pintor Cândido Portinari, o arquiteto Oscar Niemeyer foram alguns dos muitos intelectuais, artistas, jornalistas e escritores acusados de subversão.

A perseguição foi intensificada pela ação implacável do chefe de polícia da capital federal, Filinto Müller, que ficou famoso pela forma cruel e sanguinária que marcou sua atuação no combate ao comunismo. $\mathrm{O}$ caso mais emblemático foi a prisão de Olga Benário, uma judia alemã, esposa de Luís Carlos Prestes, que, embora grávida, foi entregue à Gestapo (polícia política alemã) e morta metralhada nos campos de concentração nazista de Ravensbruck, em 1942. Maria Luiza T. Carneiro afirma que, naquela época, notória era a identificação dos "elementos ligados aos órgãos de segurança com as idéias nazi-fascistas, principalmente no que dizia respeito a Filinto Müller. Até hoje se comenta a íntima colaboração existente entre eles e a Gestapo, através de entrega de judeus alemães, refugiados no Brasil”. ${ }^{3}$

Entre 5.000 e 15.000 pessoas foram detidas por todo o país. Em São Paulo, mais de 400 pessoas foram confinadas na antiga fábrica têxtil Maria Zélia, que foi transformada em presídio político. Uma dessas pessoas foi Isaltino Veiga dos Santos, uma das principais lideranças do movimento 
negro na década de 1930. Assim, a finalidade deste artigo é enfocar o drama vivido por tal liderança no cárcere do governo Vargas. Apesar de preso pela Deops sob a acusação de realizar atividades subversivas, Veiga dos Santos negou veementemente ser comunista. A questão central a ser respondida aqui é: era ele realmente comunista ou houve algum tipo de engano por parte do órgão de repressão política do governo Vargas?

\section{Isaltino Veiga dos Santos e a Frente Negra Brasileira}

Isaltino Benedicto Veiga dos Santos nasceu na cidade de Itu, interior de São Paulo, no ano de 1901. Era filho de João Benedicto dos Santos e Josephina Veiga dos Santos. De origem humilde, iniciou naquela cidade seus estudos. Ainda adolescente, revelou inclinações literárias e jornalísticas, escrevendo poesias e colaborando em algumas publicaçóes locais. Em 1918, transferiu-se para São Paulo por problemas financeiros da família. Ali passou a trabalhar em expedientes e, depois, exercendo a atividade de despachante e jornalista.

Uma outra área de atuação de Isaltino Veiga dos Santos era a política. Na década de 1920, já era um destacado ativista do meio negro e colaborou na fundação do Centro Cívico Palmares, em 1926. Dentre as diversas entidades negras de São Paulo até 1930, o Centro Cívico Palmares foi a mais importante, quer pela proposta de elevação política, moral e cultural, quer pelo grau de organização e capacidade de penetração na comunidade negra. Ele foi articulado por um grupo de ativistas (Isaltino Veiga dos Santos, Vicente Ferreira, Raul Joviano Amaral, Marcos Rodrigues dos Santos e Arlindo Veiga dos Santos) que estavam dispostos a encampar a luta contra o "preconceito de cor" em uma perspectiva mais política, sem recorrer às atividades recreativas, como os bailes dançantes. ${ }^{4}$ Em 1929, o Centro Cívico Palmares foi praticamente dissolvido. ${ }^{5}$

Dois anos depois, Isaltino Veiga dos Santos foi procurado por Francisco Costa Santos para iniciar um trabalho político de agitação em prol da fundação de uma nova entidade negra. Ele, em princípio, não se animou, pois ainda se encontrava desapontado com o fim do Centro Cívico Palmares. Porém, ante a insistência, aceitou o desafio e se entregou de corpo e alma à obra de mobilizar os "homens de cor" pela criação de uma 
entidade com os mesmos fins "elevados" do Centro Cívico Palmares. Chegou-se ao consenso de que se fazia necessário lutar pela "Segunda Abolição".

As primeiras reunióes tiveram um saldo positivo e criaram as condições para que os ativistas e grupos independentes se unissem, numa demonstração de que não deveriam continuar atuando isoladamente. Depois de amadurecida a idéia e um ingente trabalho de propaganda no meio negro, um núcleo de ativistas fundou oficialmente a Frente Negra Brasileira - União Político-Social da Raça, em 16 de setembro de 1931 (após anos da abolição jurídica da escravatura).

A FNB assumiu um projeto anti-racista que tinha como principal ideal a integração do negro, como cidadão brasileiro, à ordem social vigente. A organização cresceu rapidamente. Pelas estimativas de um de seus dirigentes, a FNB reuniu no seu auge de 25 a 30.000 filiados, ${ }^{6}$ somando os efetivos de todas as "delegações", as quais funcionavam como filiais da sede na capital paulista. Em 1936, a entidade contava com mais de 60 delegações distribuídas no interior de São Paulo e em outros Estados, como Rio de Janeiro, Minas Gerais, Espírito Santo, além de manter certo vínculo com organizaçōes de mesmo nome no Rio Grande do Sul, Bahia e Pernambuco.

No decorrer de sua trajetória (setembro de 1931 a dezembro de 1937), a FNB possuiu dois presidentes. O primeiro foi Arlindo Veiga dos Santos, que ocupou o cargo até pedir afastamento, em junho de 1934. Com sua saída, assumiu a presidência Justiniano Costa. Já Isaltino Veiga dos Santos era Secretário-Geral, o segundo cargo de maior importância na entidade. A FNB criou uma série de símbolos diacríticos (carteira de identidade, bandeira e hino), a fim de garantir visibilidade para suas ações, gerar uma identidade específica para seus associados e, ao mesmo tempo, adquirir credibilidade no seio da "população de cor" e na sociedade em geral. Todo trabalho da militância era voluntário. A principal fonte de recurso da entidade era proveniente da mensalidade dos associados.

No casarão da Rua da Liberdade, 196, onde sua sede estava localizada, a FNB mantinha um bar, salão de beleza com barbeiro e cabeleireiro, salão de jogos, oficina de costura, posto de alistamento eleitoral e uma caixa beneficente, criada para ajudar os associados, prestando-lhes auxílio médico, hospitalar, farmacêutico e funerário. Para organizar sua atuação em diversas áreas, a entidade dividia-se em vários departamentos, como o 
de Instrução ou de Cultura, Jurídico-Social, Médico, Artes e Oficios, Doutrinário, Dramático, Musical, Esportivo e Imprensa. Este último era o responsável pela publicação do jornal da entidade, $\mathrm{o} A V o z$ da Raça. O jornal era o órgão oficial de divulgação dos ideais da FNB. Com tiragem de 1.000 a 5.000 exemplares, chegou a ser lido no exterior (nos Estados Unidos e no continente africano). Era mantido com recursos da entidade e dos anunciantes.

A FNB foi a entidade do movimento negro que mais adquiriu força política nas primeiras décadas do século XX, sendo recebida em audiência pelo presidente da República, Getúlio Vargas, e pelo então governador do Estado de São Paulo, Armando de Salles Oliveira. A entidade auferiu algumas conquistas concretas no campo dos direitos civis, como eliminar a prática de proibir o ingresso de negros nos rinques de patinação e na Guarda Civil de São Paulo. ${ }^{7}$

Em 1936, a FNB transformou-se em partido político e pretendia participar das eleições do ano seguinte. Do ponto de vista ideológico, defendia um projeto de direita, ultranacionalista, com viés nitidamente autoritário. Arlindo Veiga dos Santos - o primeiro presidente da FNB - era um fervoroso opositor do comunismo e da democracia liberal, que fazia constantemente apologia do fascismo europeu. ${ }^{8} \mathrm{Em} 1937$, com a instauração da ditadura do Estado Novo, a FNB, assim como todos os partidos políticos, foi extinta.

A FNB tinha um código disciplinar rigoroso. Não se hesitava em punir todo aquele que desrespeitasse tal código. Houve vários casos de frentenegrinos que foram censurados e mesmo expulsos do quadro de associados. Um desses casos envolveu Isaltino Veiga dos Santos. Segundo relatório da Deops, ele foi desligado da Frente Negra Brasileira "por imposição da quase totalidade dos sócios e de seus diretores, por ter se afastado das diretrizes da FNB", em meados de $1933 .{ }^{9}$ Como se nota, não ficam detalhadas as razões pelas quais Veiga dos Santos foi enxotado da FNB, mas no início daquele ano ele já era acusado de ter desviado recursos da entidade e de ter cobrado dinheiro de "associados para tratar dos seus casos". ${ }^{10}$

\section{Isaltino Veiga dos Santos e a Aliança Nacional Libertadora}

Após a Primeira Guerra Mundial (1914-1919), o cenário político internacional foi caracterizado pela ascensão das idéias, de um lado, de 
extrema esquerda (comunistas); de outro, de extrema direita (autoritárias, anti-liberais e anticomunistas). Os regimes democrático-liberais entraram em crescente crise. No campo da extrema direita, os fascistas chegaram ao poder na Itália, sob a liderança de Benito Mussolini, em 1922; os nazistas conquistaram o poder na Alemanha, sob a liderança de Adolfo Hitler, em 1933. No vértice oposto, a revolução socialista de 1917 já havia triunfado na Rússia.

Com o golpe de Estado de 3 de outubro de 1930, Getúlio Vargas chegou ao poder no Brasil. O cenário político nacional foi palco de uma intensa disputa ideológica, refletindo o contexto internacional. No terreno da extrema direita, as idéias fascistas se propagavam no Brasil. Um marco desse processo foi a fundação da Ação Integralista Brasileira (AIB), em 1932. ${ }^{11}$ Presidida por Plínio Salgado, defendia um Estado integral, autoritário, nacionalista e anticomunista. O slogan da AIB - "Deus, Pátria e Família” - sintetizava seus princípios conservadores.

A difusão do fascismo brasileiro, o agravamento das condiçóes de vida das massas assalariadas e as tendências autoritárias do governo de Getúlio Vargas também provocaram a reação de diversos grupos oposicionistas. Em 1935, comunistas, socialistas e um setor dos "tenentes" se unificaram, criando uma frente popular antifascista e antiimperialista. Em janeiro daquele ano, apareceram os primeiros núcleos e, em 30 de março, realizou-se um ato público no Rio de Janeiro e foi fundada oficialmente a Aliança Nacional Libertadora (ANL). Seu presidente de honra era Luís Carlos Prestes, o "cavaleiro da esperança”, que regressara ao Brasil após sua adesão ao comunismo.

Na verdade, a ANL fazia parte da tática da Internacional Comunista, sediada em Moscou, em formar frentes populares. Tratava-se de uma política conhecida como de aliança de classes. Os partidos comunistas deviam fazer com que os operários se aliassem com as classes médias e os setores progressistas da burguesia nacional dispostos a combater o fascismo, independentemente da postura ideológica. Essa coalizão de forças, além de frear a influência fascista, teria a tarefa de preparar as massas para a conquista de governos reformistas de frente popular. "O que permanece constante [na ANL]", afirma Edgard Carone, "é a tônica antiimperialista e antifascista, porém, o programa de união nacional am- 
plia-se, sempre como tentativa de tornar as suas reivindicações simpáticas a um maior número de forças possíveis". ${ }^{12}$

A ANL rompia o velho esquema dos partidos estaduais dominados pelas oligarquias. Sob a bandeira de "pão, terra e liberdade", era o primeiro movimento político-nacional de massas com objetivos democrático e reformista, que representava um desafio ao sistema vigente. Seu programa propugnava a suspensão do pagamento de todas as dívidas externas imperialistas, a imediata nacionalização das empresas imperialistas, a redistribuição dos latifúndios e a proteção aos pequenos e médios proprietários rurais, o livre exercício das liberdades públicas e a criação de um governo verdadeiramente popular. Também foram feitos chamados para que os grupos específicos, como mulheres e negros, assumissem o programa da ANL.

Depois que Isaltino Veiga dos Santos foi expulso da Frente Negra Brasileira, ele teria articulado a Federação Nacional dos Negros do Brasil, com sucursais no Rio de Janeiro. Mas, dado o desconhecimento da natureza, da atuação e do projeto político-ideológico de tal organização, o órgão de repressão política do governo Vargas considerava seus adeptos "suspeitos". ${ }^{13}$ Em determinada ficha investigativa produzida pela Deops, Veiga dos Santos era apresentado como um elemento de "muito prestígio" no seio da Frente Negra Brasileira: "Fundador da Federação Nacional dos Negros do Brasil. Diz-se que fundou essa entidade com o intuito de levar seus adeptos para a Aliança Nacional Libertadora. Costumava freqüentar as reuniōes sindicais, principalmente se promovidas pelo Sindicato Unitivo dos Ferroviários da Central do Brasil. Redigiu muitos boletins subversivos, os quais foram distribuídos em bairros desta Capital". ${ }^{14}$ Apesar dessas informações contidas na ficha investigativa elaborada pela Deops, é preciso ter uma posição de prudência. Não há maiores indícios de que Arlindo Veiga dos Santos era um ativista sindical, tampouco que ele tenha empreendido algum plano de aliciar os negros para a ANL.

Em livro de memórias, José Correia Leite (uma antiga liderança do meio negro) apresenta uma outra versão para esses fatos: Isaltino Veiga dos Santos seria um "aventureiro, [que] estava na Frente Negra com a idéia de conseguir qualquer coisa pra ele”. Em seguida, Correia Leite lembra: "Depois de algum tempo fora da Frente Negra, [Veiga dos Santos] entrou num movimento político de esquerda muito sério. Foi quando começou a 
Aliança [Nacional] Libertadora. [...] Pensaram mesmo que ele fosse um homem de esquerda. Deram um emprego a ele no jornal $A$ Platéa, que estava nas mãos de um grupo de esquerda da época". ${ }^{15}$

De fato, como organização de base popular, a Aliança Nacional Libertadora (ANL) "procurou envolver os negros". ${ }^{16}$ Em termos mais precisos, a ANL não ignorou totalmente as questões da população negra. № 13 de maio de 1935, ela organizou um grande ato comemorativo da abolição da escravatura e levantou a bandeira do combate ao racismo. $\mathrm{O}$ manifesto que Luís Carlos Prestes (chefe da ANL) lançou à nação, em 5 de julho de 1935, defendia, dentre outras coisas, as liberdades civis e a igualdade racial. ${ }^{17}$

Em apenas três meses de existência, a ANL abriu mais de 1.600 sedes por todo o país. Robert M. Levine estima que a organização reuniu aproximadamente 180 mil membros. ${ }^{18}$ A aglutinação "das massas é tão inesperada que governo, integralistas e classes dirigentes temem a política progressista da Aliança”. ${ }^{19}$ Em julho de 1935, Vargas determinou o fechamento de sua sede e a colocou na ilegalidade. $\mathrm{O}$ pretexto do fechamento foi o discurso de Luís Carlos Prestes de 5 de julho, quando defendeu as seguintes palavras de ordem: "Por um governo popular revolucionário" e "Todo o poder à Aliança Nacional Libertadora!”. O chefe da Polícia Civil, Filinto Müller, prontamente informou a Vargas que os "comunistas" tinham um plano de tomada do poder. $\mathrm{O}$ ministro da Justiça então elaborou um decreto que declarava a ANL ilegal, com base na Lei de Segurança Nacional. ${ }^{20}$

Apesar de fechada, a ANL funcionou na ilegalidade, publicando boletins de propaganda e ataques ao governo e ao integralismo. No entanto, o governo intensificou a repressão aos núcleos da entidade. Diante dessa situação, os elementos da ANL resolveram fundar uma nova organização, a Frente Popular pela Liberdade, no Rio de Janeiro, em novembro de 1935. Depois ela se constituiu em São Paulo e seu manifesto foi assinado pelo General Miguel Costa, Coronel Colombo de Melo Matos, Danton Vampré (advogado), Caio Prado Júnior, e os cientistas José Maria Gomes, Waldemar Rangel Belfort de Mattos e o líder negro Isaltino Veiga dos Santos. O manifesto era uma denúncia dos problemas sociais brasileiro Segundo Edgard Carone, ele "fala da perseguição governamental aos sindicatos e operariado, da fascistização do governo etc.". Entretanto, a "Intentona" Comunista de novembro de 1935 (com os levantes militares de Natal, 
Recife e Rio de Janeiro) impede a "nova tentativa de ter continuidade a ação. Afinal, em dezembro de 1935, a sentença do Juiz da $1^{\text {a }}$. Vara, Dr. Edgard Ribas Carneiro, dissolve definitivamente a Aliança Nacional Libertadora". ${ }^{21}$

\section{O drama de Isaltino Veiga dos Santos na prisão}

Com a derrota da "Intentona" Comunista, aumentou a escalada de restrição aos direitos democráticos e de perseguição aos movimentos sociais. Getúlio Vargas decretou um mês de estado de sítio. Este se ampliou e foi transformado em estado de guerra, por período de 90 dias. Em 14 de dezembro, foi criada a Lei de Segurança Nacional. Essas medidas permitiram que a polícia agisse livremente na caça aos comunistas e esquerdistas de um modo geral. Nelson W. Sodré assinala que a polícia passou a cometer toda sorte de arbitrariedade: matava as pessoas suspeitas nas ruas, invadia as casas a qualquer hora, forjava histórias, falsificava documentos, arquitetava conspirações, torturava os acusados e as testemunhas. Instalou-se o "processo de denúncia sob qualquer pretexto, retirou-se ao cidadão o direito de escrever, de falar, de reunir-se com outros, de criticar, de protestar, de discutir, de conversar, de divergir" ${ }^{22}$ Dali em diante, toda pessoa que se recusava a apoiar o governo, ou hesitava em fazê-lo, poderia acabar sendo rotulada de comunista. Para Rose, mais naquele momento do que em qualquer outro do passado, os comunistas eram apontados como inimigo público número um. "A onda de terror que surgiu nas últimas semanas de 1935", argumenta esse autor, "foi a maior dessa espécie na história do país". ${ }^{23}$

Os assinantes do Manifesto da Frente Popular pela Liberdade foram presos pela Deops (órgão de repressão do governo Vargas). Um dos assinantes, Isaltino Veiga dos Santos, foi detido no dia 27 de novembro de 1935. Levado para o presídio político de Maria Zélia, declarou que fora "hostilizado" e sofreu "humilhações", ${ }^{24}$ "maus-tratos" e "espancamentos" 25 para confessar sua participação nas fileiras do comunismo e de ter desenvolvido atividades de caráter subversivo.

As declarações de Isaltino V. dos Santos faziam sentido, pois a situação dos detentos no presídio Maria Zélia não era nada aprazível. Com 
uma aparência sinistra, o presídio media pouco mais de quatrocentos por mil metros. Na parte interna, era dividido em oito pavilhões (o A, B, C, D, E, F, G e H) baixos, de madeira, que ficavam lotados. Ele ficava situado no bairro do Belém, próximo ao rio Tietê. E era do Tietê, a principal via do sistema de esgoto da cidade de São Paulo, que o Maria Zélia tirava a água para beber, sem nenhum tipo de tratamento. O chefe dos guardas, Adriāo de Almeida Monteiro, era conhecido por ser cruel e odioso. Muitos prisioneiros eram espezinhados e tratados à base de grosserias, empurrões e tapas dos carcereiros. As latrinas fediam. Já a comida servida era de qualidade bem duvidosa. Era comum encontrar o feijāo podre e, por cima da refeição, restos do cuspe dos guardas. Os presos reclamavam que o pessoal da enfermaria era faltoso no trabalho e que os remédios tinham de ser comprados. A tuberculose e várias outras enfermidades infestavam aquele ambiente pouco salubre. As tentativas de fuga não eram tratadas com complacência. Em uma delas, 26 presos tentaram fugir, mas os guardas foram alertados. Resultado: a repressão foi violenta, deixando um saldo de três detentos mortos a tiros. ${ }^{26}$

No período em que esteve detido, Isaltino Veiga dos Santos redigiu uma série de requerimentos e correspondências para as autoridades policiais, a fim de provar sua inocência e negar seu envolvimento com o comunismo. Em um dos requerimentos - escrito em 17 de abril de 1936 e endereçado a Egas Botelho, Superintendente da Ordem Política e Social (Deops) -, ele imprimia um tom sensacionalista para relatar os problemas que enfrentava ao ser privado da liberdade: "A minha família caminha para um completo estado de miserabilidade, devido mesmo a minha condição de preso, que nada pode produzir para a subsistência dos seus, acresce ainda, Dr. Egas Botelho, que, também minha senhora nada ou quase nada pode fazer, porque temos criança de colo, que nasceu 3 ou 4 dias antes da minha prisão". Rogando pela filha que nascera no período em que se encontrava no cárcere, Isaltino Veiga dos Santos continuava: "pela honra dessa criança, dessa menina, que ainda não conhece o colo e o carinho do seu pai, que eu juro ser inocente, e nada haver praticado em desrespeito às leis do meu país; e, mais uma vez afirmo, não sou comunista nem extremista, e nem pertenci à Aliança [Nacional Libertadora]; combati, combato, e combaterei sempre esse credo; pois que tenho amor a mi- 
nha pátria, a minha família e sou católico apostólico e romano; e peço por isso em nome de Deus, que V. Excia. não continue a me conservar entre inimigos". 27

Em requerimento de 13 de maio de 1936, quase um mês depois, Isaltino Veiga dos Santos escreveu novamente a Egas Botelho. Lembravase da data da Abolição e associava o seu "flagelo" àquele vivido pelos descendentes de africanos na época da escravidão: "Há quarenta e oito anos passados, na data de hoje, o Brasil libertava a gente negra nacional da escravidão, é, pois, por essa razão, que, como negro que sou, venho mais uma vez, solicitar encarecidamente a V. Excia. a minha liberdade [...]”. Isaltino V. dos Santos pintava um quadro dramático para a situação em que ele e a família atravessavam: "No dia de hoje, em meu nome e no de minha família, que chora constantemente a minha ausência, eu peço encarecidamente Exmo. Snr. Dr. Egas Botelho, que seja hoje o meu 13 de Maio, a fim de que eu possa abraçar os entes queridos que compóem a minha família”. Por fim, aquele líder negro lamuriava, evocando a "mãe negra, que embalou o Brasil pequenino, mãe negra essa, que para mim é representada pela minha, que inconsolável chora a todo o momento por me ver preso, eu espero do espírito justiceiro de V. Excia., a minha restituição à liberdade”. ${ }^{28} \mathrm{O}$ esforço retórico de Isaltino Veiga dos Santos foi em vão; o requerimento foi praticamente ignorado pelo destinatário.

Em 15 de maio de 1936, dois dias depois, Veiga dos Santos voltava a encaminhar um requerimento para Egas Botelho e fazia uma longa exposição de sua trajetória política. $\mathrm{O}$ mote da argumentação era sua suposta aversão ao comunismo:

Desde 1932, venho eu trabalhando na repressão ao comunismo em nosso Estado, sempre de acordo e ao lado dos Srs. Joaquim Dutra da Silva, Paulo Dutra da Silva, José Carlos de Ataliba Nogueira, Arlindo Veiga dos Santos, Boris Poteckim, Altino Guimarães, e muitos outros, todos fundadores da "Liga Anti-Comunista", que pouco tempo teve de vida, pela falta exclusiva do apoio material de que necessitava; continuando porém os seus membros a trabalhar, inclusive eu, nessa campanha patriótica, na Frente Negra Brasileira, da qual sou um dos principais fundadores, idêntico trabalho de repressão, foi organizado, criando eu nessa ocasião, um semanário, intitulado "A Voz da Raça", onde fazíamos uma campanha inteligente contra o comunismo; criamos ainda as sessóes domingueiras, na sede da sociedade, onde a 
nosso convite, falavam oradores de comprovada autoridade na matéria, mostrando à assistência com fatos, argumentos e mesmo com documentação, a perniciosidade de tão repelente credo; à Polícia, milhares de vezes, com o auxílio do Sr. Boris Potekin, forneci relatórios com nomes e residências de pessoas das quais suspeitávamos exercer atividades extremistas, pessoas essas na maioria das vezes estrangeiras; o Exmo. Snr. Dr. Leite de Barros, atual Secretário da Segurança, que me conhece por apresentação do Dr. Armando Franco Soares Caiuby (pois que este último conhece-me desde criança), muitas vezes me viu no Gabinete de Investigações, tratando desses assuntos, se bem que nunca tivesse sido funcionário da polícia, embora muitas vezes tivesse pretendido ser.

Todos os nomes que acabei de citar comprovam a qualquer momento as minhas afirmativas; preso que fui, no dia 27 de novembro do ano passado, não me foi possível, se bem que pedisse, avistar-me com V. Excia., ou com outra qualquer autoridade, razão pela qual venho sofrendo horrivelmente há já quase seis meses, ao ponto de estar sujeito a ser sacrificado pelos próprios presos, pois que agredido já tenho sido; já muito expus a V. Excia., com referência à minha situação ante os demais presos, ela porém agravouse do dia 13 a esta parte, com a publicação do relatório do Snr. Dr. Tavares da Cunha em quase todos os jornais desta capital, razão esta pela qual me encontro neste presídio, só, num xadrez do prédio velho, porque nos outros, logo a minha chegada fui afrontado pelos presos que ali se acham, tudo mais, possivelmente, já é do conhecimento de V. Excia. Diante pois, da clara exposição que aqui acabo de fazer, há outras havendo endereçada a V. Excia., eu, que tenho consciência de haver sido sempre útil à Polícia do meu Estado, na campanha de repressão ao comunismo, continuando a ser, até mesmo de armas na mão se necessário for, creio e julgo ser digno de melhor sorte; embora constantemente haja derrubado lágrimas, nas minhas intermináveis noites de vigília, a pensar nos meus entes queridos e no desassossego da família nacional, afirmo que essas lágrimas, não são de covardia, e sim, por me encontrar humilhado diante daqueles que são meus inimigos, hoje, amanhã e sempre.

É, pois, Exmo. Snr. Dr. Egas Botelho, pelas razões aqui expostas, que eu, abaixo assinado, venho solicitar encarecidamente que, até que se aclare de toda a minha situação, e na impossibilidade se houver de uma liberdade integral, conceda-me V. Excia. uma condicional, conservando-me preso com guarda a vista, na minha própria residência, onde poderei ser útil a minha família, a V. Excia. e conseqüentemente à sociedade.

Confiando no espírito justiceiro de V. Excia., aguardo vosso pronunciamento favorável. ${ }^{29}$ 
Em fevereiro de 1936, Filena Veiga dos Santos, esposa de Isaltino Veiga dos Santos, "com 24 anos de idade, doméstica, residente a rua Major Diogo, 93, distrito da Bela Vista nesta capital”, já havia escrito um requerimento endereçado ao Exmo. Snr. Dr. Arthur Leite de Barros, Secretário da Segurança Pública de São Paulo. Nele, vinha expor e requerer o seguinte: estando o seu marido Isaltino Benedicto Veiga dos Santos, brasileiro, jornalista, detido desde o dia 27 de novembro de 1935, e atualmente no presídio político "Maria Zélia", na capital paulista, "sem que, até esta data, nada se apurasse contra o mesmo, eis que nunca exerceu atividade nociva às instituições políticas e sociais do país, como poderão comprovar as diligências que ordena o digno superintendente da Ordem Política e Social, e as informações que se dignar V. Excia. solicitar às autoridades policiais, entre elas o Exmo. Sr. Dr. Armando Soares Caiuby, delegado de repressão à vadiagem". Após negar que o marido realizasse atividades "subversivas", Filena Veiga dos Santos ratificava que a detenção prolongada dele, "sem fundados motivos que a justifique", só estava causando danos moral e material à sua família, composta da suplicante, filhos e sobrinhos, todos menores, dos quais é também seu marido arrimo. Portanto, a detenção de Isaltino V. dos Santos estava causando "angustiosas privações” para a família, sendo que a "miséria completa se aproximava", o que não poderia admitir o Estado moderno, "que tem por uma de suas principais funções proteger a família numerosa e pobre, como é a suplicante e seu marido". Em função disso, Filena V. dos Santos clamava o "alto critério" do Secretário de Segurança Pública, Arthur Leite de Barros, no sentido de que atendesse ao pedido de restituir a liberdade do marido, uma vez que nada tinha sido apurado contra o mesmo. "Assim fará V. Excia. um ato de inteira justiça”, arrematava a requerente. ${ }^{30}$

Apesar dos apelos da esposa, o quadro desfavorável a Isaltino Veiga dos Santos não se alterou. Para que não pairassem dúvidas, em 13 de março de 1936, cerca de um mês depois, Egas Botelho, Superintendente da Deops em São Paulo, determinou que o agente policial João Agostinho preparasse um novo relatório sobre o acusado. Após consultar "documentos e mais papéis existentes" no arquivo da Deops, João Agostinho dizia que Isaltino Veiga dos Santos era um "franco aliancista", que era membro da direção da Frente Popular pela Liberdade e um dos signatários do ma- 
nifesto com que essa "agremiação extremista" se apresentou a público. Para complicar ainda mais a situação, João Agostinho consignava que Isaltino Veiga dos Santos era freqüentador assíduo de reunióes de sindicatos e especialmente do sindicato Unitivo dos Ferroviários da Central do Brasil. Além disso, ele teria "redigido boletins subversivos, exercendo, enfim, toda sorte de atividades comunistas". Ao finalizar seu relatório, João Agostinho emitia seu "veredicto" sobre o acusado: "Somente pelo acima enunciado pode-se avaliar de perto da nocividade de Veiga dos Santos". ${ }^{11}$

Em julho de 1936, depois de mais de seis meses da prisão de Isaltino Veiga dos Santos, o respeitado irmão Arlindo Veiga dos Santos (ex-presidente da Frente Negra Brasileira e Chefe Geral Patrianovista) resolveu se pronunciar e tomar posição no caso. Ele escreveu uma longa carta para Egas Botelho, em que afirmava de maneira categórica: Isaltino Veiga dos Santos não é comunista, afinal, "quem tem religião, quem ama a família como ele não pode, de modo nenhum, ser comunista, visto que tal virtude aberra das normas do falso credo moscovita”. Segundo Arlindo V. dos Santos, seu irmão foi explorado em sua "boa-fé e captado por esperanças falsas instigadas pelos perversos [...] inimigos da Pátria”. De baixa formação cultural, ele seria incapaz de distinguir entre os bons e falsos princípios. Teria sido essa a razão pela qual Isaltino V. dos Santos assinou o manifesto da Frente Popular pela Liberdade. Ademais, os comunistas o teriam encontrado em um momento vulnerável do ponto de vista material: "estava em péssima situação econômica, desempregado, sofrendo as conseqüências de tal situação". Já no que diz respeito ao aspecto moral, não seria dos melhores o seu estado psicológico. Há pouco tempo, arranjara um emprego, por meio de um amigo, numa grande empresa estrangeira da capital, "sem que, todavia, os chefes tivessem conhecimento pessoal dele; sem saberem, portanto, que ele era negro. Certamente os ilustres arianos hóspedes de nossa Pátria não desejavam um negro nos seus escritórios. Deram uma desculpa, e não o receberam. Outros e outros fatos iam gerando um sentimento de revolta...”. Contudo, Arlindo V. dos Santos era incisivo: apesar de estar atravessando uma fase de dificuldades, seu irmão jamais advogaria a causa comunista. Ele lembrava que, por meio da Frente Negra Brasileira, ambos empreenderam uma propaganda "anti-socialista e antibolchevista”, o que mereceu elogios do Sr. Lodjinsky da 
"Entente Internationale contre la III Internationale", no seu boletim E. I. A. Baseando-se na trajetória político-ideológica do irmão, Arlindo V. dos Santos ventilava a seguinte explicação: "precisavam os comunistas de um agente para os negros... e por certo Isaltino não era o agente desejável”. Mais ainda: se este soubesse que a "Frente Popular pela Liberdade era continuação da Aliança Nacional Libertadora, comunista, não entraria naquilo”. Para finalizar a carta, Arlindo V. dos Santos fazia uma invocação para o Superintendente da Deops: "se julga V. Excia. que a minha linguagem aqui não é mais do que a da verdade, e não há no inquérito coisa de mor peso para invalidar o peso das minhas, espero que V. Excia. tome na devida conta o que lhe alego e abrevie a reclusão do acusado Isaltino Veiga dos Santos" ${ }^{32}$

Arlindo Veiga dos Santos tinha razão quando dizia que seu irmão, na época em que era Secretário-Geral da Frente Negra Brasileira, colaborava com a polícia política na perseguição ao comunismo. Em 1933, num ofício encaminhado a Armando Soares Caiuby, então Delegado de Ordem Política e Social, Isaltino Veiga dos Santos relatava que

nós os frentenegrinos queremos contribuir ajudando a V. Excia., e as demais autoridades constituídas, a trabalharem para o completo saneamento da desordem de inteligência, ora reinante em nossa pátria, muito especialmente neste Estado, onde abertamente se fala em separatismo, comunismo e outras ideologias exóticas que só têm servido para embaraçar o trabalho dos homens que presentemente governam nossa querida pátria. ${ }^{33}$

Se naquele instante Isaltino Veiga dos Santos desqualificava o comunismo de "ideologia exótica", um ano antes ele escreveu um artigo no jornal da grande imprensa, Diário da Noite, condenando os "representantes da mentalidade exploradora liberal-democrática falida e desmoralizada" ${ }^{34}$ A crítica ao comunismo e ao regime liberal-democrático constituiu a base do programa fascista na década de 1930, que no Brasil teve como principal representante o movimento integralista. $\mathrm{O}$ interessante é que, no período em que era dirigente da FNB, Isaltino Veiga dos Santos admitia tacitamente que seu ideal político coincidia com o integralista. Ao ponderar sobre o 13 de Maio, dia da abolição da escravatura, ele veiculava no jornal daquela organização, $A$ Voz da Raça: "A nossa luta visa, está visto, a nossa completa emancipação social e política... O negro quer, e precisa 
estar em toda parte onde se fale em nacionalismo integral". ${ }^{35}$ Ao menos até ser desligado da FNB, em meados de 1933, aquele líder negro preconizava um projeto político de direita, nacionalista, nos moldes integralistas. Por que, então, um pouco mais de dois anos depois ele assinaria um manifesto de uma organização de esquerda (a Frente Popular pela Liberdade), que era influenciada pelos comunistas?

Em 29 de janeiro de 1936, Isaltino Veiga dos Santos escreveu uma longa carta endereçada a um "bom amigo" da família, o Ilmo. Snr. Dr. Armando Franco Soares Caiuby. Ali, ele explicava a atitude que tivera no episódio que resultou em sua prisão:

Sou católico apostólico e romano, como toda minha família, e sobretudo intransigentemente nacionalista, desta última qualidade tenho dado sobejas provas publicamente - assinei o manifesto da Frente Popular, porque em todas as ocasióes, estive sempre a postos, para a defesa da minha raça e conseqüentemente da minha Pátria, mesmo porque, a maioria dos elementos da raça, não possuindo instrução necessária, e muito menos uma visão larga no ponto de vista político-social, serviu sempre de engodo às exploraçôes dos eternos descontentes, assim sendo, para lá me infiltrei, a fim, de como sempre procedi, tomar posição em benefício de minha raça, continuando como continuarei sempre fiel à minha divisa, Deus, Pátria e Família, embora, por convicções próprias, não seja também integralista. A minha infiltração na Frente Popular não deu, é verdade, resultados positivos, por ter a mesma morrido no seu nascedouro, nem sequer uma reunião consegui assistir, a não ser a que foi convocada para tratar da legalização dos Estatutos. ${ }^{36}$

Isaltino V. dos Santos explicava a Armando Franco Soares Caiuby que assinou o manifesto da Frente Popular pela Liberdade para defender os interesses da "raça" e da "pátria". Em outras palavras, ele teria se infiltrado no movimento de esquerda sucessor da Aliança Nacional Libertadora (ANL) para evitar que seus "irmãos de cor" fossem manipulados politicamente ou servissem de massa de manobra em algum plano subversivo. ${ }^{37}$ No final, ele declarava que seus verdadeiros ideais políticos se traduziam no slogan "Deus, Pátria e Família". Como já foi assinalado, este slogan consubstanciava os dogmas integralistas no Brasil. Mas é difícil assegurar que Isaltino V. dos Santos falava a verdade. Não se pode esquecer que ele se encontrava na condição de réu no processo; preso sob a acusação de 
professar uma ideologia considerada criminosa na época: o comunismo. Assumir posições do movimento integralista naquela circunstância era um ato de autodefesa, tendo em vista que esse movimento era radicalmente anticomunista. De toda sorte, procurar o apoio dos integralistas foi uma das táticas daquele líder negro para se livrar da pecha de subversivo. Nesse sentido, o relato do deputado integralista Carlos Fairbanks era revelador. Ele "lera da tribuna do Congresso Estadual [de São Paulo] uma carta que recebera de Isaltino V. dos Santos, na qual este alegava inocência e lhe pedia providências para a sua liberdade. Disse o deputado Fairbanks que não acreditava ser Isaltino V. dos Santos elemento comunista, entregando a missiva à consideração dos seus pares" ${ }^{38}$

Embora não pudesse ser qualificado propriamente como integralista, Isaltino Veiga dos Santos desfraldava o ideário da direita e jamais abraçou efetivamente a causa da ANL ou da sua organização sucessora, a Frente Popular pela Liberdade. Assim, é plausível pensar que ele ingressou nesses movimentos menos por convicção político-ideológica e mais por conveniência: conseguir um meio de ganhar a vida, uma vez que estava desempregado. E foi exatamente isso o que aconteceu. Em 1935, ao conquistar a confiança dos movimentos de esquerda, Veiga dos Santos obteve um emprego no jornal oposicionista A Platéa.

$\mathrm{Na}$ longa carta que escrevera para Armando Franco Soares Caiuby em 29 de janeiro de 1936, Isaltino Veiga dos Santos ainda descrevia que em função dos "companheiros de luta" terem descoberto que ele colaborava com os órgãos de repressão política ${ }^{39}$ - sua vida no presídio passou a ser um "verdadeiro inferno", em que "afrontas" a ele dirigidas tornaram-se "constantes e atrevidas". Para salvaguardar a vida de Veiga dos Santos, haja vista que ele próprio admitia que poderia levar a "pior", a direção do presídio decidiu transferi-lo de "xadrez". No final da carta, aquele líder negro solicitava a ajuda do "bom amigo" da família. ${ }^{40}$

Armando Franco Soares Caiuby parece ter ficado sensibilizado. Em 31 de janeiro de 1936, dois dias depois de ter recebido a carta de Isaltino Veiga dos Santos, ele elaborou e encaminhou um ofício a Egas Botelho para atestar a versão de que Veiga dos Santos não era comunista:

O Isaltino é rapaz inteligente e, com esforço próprio, tornou-se literato (sic), jornalista e foi o organizador da Frente Negra Brasileira. [...] Depois 
de 1932, terminando a Revolução [Constitucionalista], o Isaltino deixou a Frente Negra, pois esta se bipartia na política interna e no programa. Deixando a Frente Negra, tem, mensalmente, me procurado para um emprego (sic) e quer trabalhar na polícia.

Como eu conheço bem a família do Isaltino, é que escrevo esta. $\mathrm{O}$ pai do Isaltino foi o eterno cozinheiro dos jesuítas do colégio de Itu. Com a extinção do colégio é que a família para cá se mudou. A mãe é cozinheira de forno e fogão, tendo trabalhado nas principais casas de Itu e Capital. As irmãs são costureiras e o irmão é o Dr. Arlindo, professor do Ginásio São Bento.

[...] O Isaltino e o Arlindo muito me ajudaram na repressão ao comunismo. Foram elementos combativos da Liga Contra o Comunismo em 1932 e [19]33 e me ajudaram também na Ordem Social [Deops]. Por isso, conhecendo o menino, freqüentando ele minha casa, sei que não é comunista. ${ }^{41}$

Não se sabe se as informações contidas no ofício elaborado por Armando F. Soares Caiuby foram levadas em consideração, mas o fato é que a Deops não conseguiu reunir elementos comprobatórios do engajamento de Isaltino Veiga dos Santos nas lides do comunismo ou em atividades de caráter subversivo. Assim, em 24 de dezembro de 1936, a prisão daquele líder negro foi relaxada e ele respondeu ao processo em liberdade. Rose observa que, antes de serem soltas, as pessoas detidas no Maria Zélia, e especialmente as que tinham sido torturadas, eram ameaçadas e obrigadas a ficar em silêncio, ou seja, nunca tornarem público o que acontecera com elas no cárcere. ${ }^{42} \mathrm{~A}$ maioria dos ex-presos então se negou a falar de suas experiências. Um deles foi Isaltino Veiga dos Santos, que tinha noção dos riscos que ainda corria em ser preso novamente e se tornar vítima de algo mais draconiano.

De toda sorte, não foram dirimidas as suspeitas que recaíam sobre aquele líder negro, o qual passou a ser vigiado pela Deops. Um agente policial o acompanhava diariamente, anotando tudo o que ele realizava ao sair de casa: "Cerca das 18 horas o observado dirigiu-se a rua Barão de Ijuhy, residência do presidente da 'Frente Negra Brasileira', onde permaneceu por algum tempo. Dirigiu-se em seguida à rua 13 de Maio, 193, isto às 19 horas mais ou menos, residência de um seu aluno, onde foi lecionar. Às 20 horas regressou à sua residência, não mais saindo e não recebendo visitas até o final da observação". ${ }^{43} \mathrm{O}$ processo acusatório de 
Isaltino Veiga dos Santos e de todos que assinaram o manifesto da Frente Popular pela Liberdade tramitou no Tribunal de Segurança Nacional (TSN). Quase dois anos depois do relaxamento da prisão, em 21 de dezembro de 1938, uma sentença do desembargador F. de Barros Barreto, presidente do TSN, absolveu Isaltino V. dos Santos e outros assinantes (Caio Prado Júnior, Danton Vampré e José Maria Gomes) do referido manifesto. Com aquela sentença, chegava ao fim o drama de uma liderança negra que pagou o ônus de sua postura paradoxal: embora comungasse de convicçóes político-ideológicas de direita, foi detido pela polícia política e processado por participar de uma organização de esquerda.

Se de comunista Isaltino Veiga dos Santos não tinha nada, por que ele, mesmo assim, deu motivos para ser acusado e preso como tal? Uma das respostas possíveis foi aquela dada por José Correia Leite, seu antigo companheiro de movimento negro: Isaltino V. dos Santos era um "oportunista”, que se teria enfileirado nos movimentos oposicionistas, essencialmente, por interesses pecuniários. Como ele conseguiu emprego no jornal de esquerda A Platéa após seu afastamento da Frente Negra Brasileira, precisava sinalizar algum grau de afinidade ideológica com seu novo ambiente de trabalho e um dos meios encontrados para isso foi assinar o manifesto político de lançamento da Frente Popular pela Liberdade, a organização sucessora da ANL. Isto não significa que Veiga dos Santos, em seu íntimo, tenha abandonado o ideário político de direita, tampouco se convertido ao "credo" comunista.

Todavia, convém ter reticências para a explicação de cunho memorialístico que José Correia Leite deu na década de 1980. Além de a memória ser seletiva e passível de imprecisões, não se pode desconsiderar que Correia Leite era adversário político de Isaltino Veiga dos Santos no movimento negro - fato que deve ter concorrido para que sua explicação fosse enviesada. A resposta mais convincente para o que aconteceu está relacionada com um contexto específico. $\mathrm{Na}$ década de 1930, a questão racial emergiu de forma politizada e articulada com outros temas, como nacionalismo e cidadania. Frações da população negra manifestaram o desejo de representação política e de intervenção no destino da nação. Não encontraram, porém, o devido respaldo. É verdade que tanto os movimentos políticos de direita (como a Ação Integralista Brasileira) quanto o de esquerda 
(como a Aliança Nacional Libertadora) propalavam um discurso a favor da radical transformação na estrutura social e defendiam um projeto nacionalista, mas também é verdade que jamais priorizaram o "problema do negro".

Isso ajuda a entender os dilemas de Isaltino Veiga dos Santos. Na sua opinião, mais relevante do que a opção político-partidária era a defesa dos "ideais patrióticos". E defender o Brasil significava advogar em benefício de seu principal patrício: o negro. A postura de Veiga dos Santos não era tida como uma excrescência. Para a maior parte das lideranças negras da década de 1930, a conquista da cidadania independia do tipo de posicionamento político e ideológico; o mais importante era a capacidade de organização e mobilização da "população de cor", bem como sua habilidade para cavar espaços e forjar apoios e alianças. Em outros termos, a retórica em prol da integração do negro teria primazia sobre as polarizações partidárias. Em função disso, as filiações e fidelidades políticas e coerências ideológicas eram vistas como secundárias ou subsidiárias.

Se aquele líder negro não foi nenhum subversivo, também não foi vítima de engano por parte do órgão de repressão política do governo Vargas. Afinal, ele assinou o manifesto da Frente Popular pela Liberdade, uma organização de esquerda que fazia oposição ao governo. Para a polícia política, os agrupamentos da esquerda representavam um inimigo a ser combatido, por isso a perseguição deles foi permanente durante o período de vigência do governo Vargas, mas foi particularmente intensificada entre 1935 e 1937, justamente no interregno da tentativa de golpe dos comunistas e da implantação do Estado Novo. ${ }^{44}$ Nesse período, a perseguição da polícia se estendeu a todos os ativistas e simpatizantes da esquerda, sendo ou não comunistas.

Para finalizar esse artigo, cumpre fazer duas observaçôes. As idiossincrasias de Isaltino Veiga dos Santos são uma espécie de sismógrafo de como a parcela da "população de cor" que militava no movimento negro pensava as formas de participação, aliança e organização. Já a segunda observação não pode ser negligenciada pelas futuras pesquisas. $\mathrm{O}$ caso de Veiga dos Santos demonstra como é possível identificar lideranças negras que, sem abdicar de sua consciência racial, tiveram participação ativa no jogo da correlação de forças políticas no governo Vargas e, especialmente, atuaram nos movimentos protagonizados pela esquerda (e direita) brasileira nas primeiras décadas do período republicano. 


\section{Notas}

${ }^{1}$ Ofício ao Sr. Egas Botelho, Superintendente de Ordem Política e Social, 11 de fevereiro de 1936. Prontuário no 2018, Isaltino Veiga dos Santos. DEOPS/SP, Arquivo Público do Estado de São Paulo (AESP).

${ }^{2}$ AGGIO, Alberto e BARBOSA, Agnaldo de Sousa e COELHO, Hercídia Mara Facuri. Política e sociedade no Brasil (1930-1964). São Paulo: Annablume, 2002, p. 32.

${ }^{3}$ CARNEIRO, Maria Luiza Tucci. $O$ anti-semitismo na era Vargas: fantasmas de uma geração (1930-1945). São Paulo: Brasiliense, 1988, p. 117.

${ }^{4}$ SILVA, José Carlos Gomes da. Os suburbanos e a outra face da cidade. Negros em São Paulo (1900-1930): cotidiano, lazer e cidadania. Dissertação de mestrado apresentada ao Programa de Pós-Graduação em Antropologia da Unicamp. Campinas, SP, 1990, p. 123.

5 DOMINGUES, Petrônio. Uma história não contada: negro, racismo e branqueamento em São Paulo no pós-abolição. São Paulo: Ed. Senac, 2004, p. 333.

${ }^{6}$ PINTO, Regina Pahim. O movimento negro em São Paulo: luta e identidade. Tese de doutorado apresentada ao Programa de Pós-Graduação em Antropologia da USP. São Paulo, 1993, p. 91.

${ }^{7}$ ANDREWS, George Reid. Negros e brancos em São Paulo (1888-1988). Trad. Magda Lopes. Bauru-SP: Edusc, 1998, p. 234.

${ }^{8}$ DOMINGUES, Petrônio. A insurgência de ébano. A história da Frente Negra Brasileira (1931-1937). Tese de doutorado apresentada ao Programa de Pós-Graduação em História Social da USP. São Paulo, 2005.

${ }_{9}^{9}$ Relatório policial. Prontuário no 1538, Frente Negra Brasileira. DEOPS/SP, AESP.

${ }^{10}$ A Voz da Raça. São Paulo, 01 de abril de 1933, p. 1.

${ }^{11}$ TRINDADE, Hélgio. Integralismo: o fascismo brasileiro na década de 30. 2ª ed., São Paulo-Rio de Janeiro: Difel, 1979.

${ }^{12}$ CARONE, Edgard. A República Nova (1930-1937). 2ª ed., São Paulo: Difel, 1976, p. 266.

${ }^{13}$ Ofício ao Sr. Delegado Adjunto da Seção de Investigaçōes do Deops. Prontuário no 2018, Isaltino Veiga dos Santos. DEOPS/SP, AESP. Segundo o relatório da Deops, a Federação Nacional dos Negros era composta por Isaltino Veiga dos Santos, Benedicto Sodré, Estefanio Benedicto, Eustachio de Almeida, Manoel da Rosa Lima, Estella Silva de Miranda, Antonio de Almeida Prado, Sinval Neves, José de Almeida, Milton de Castro Santos, Benedicta Augusta de Almeida, Maria Augusta de Almeida, Darcy Maria de Almeida, Dulce dos Santos, Benedicta Nazareth dos Santos, José Correia Leite, Sebastiāo de Oliveira, Oscar de Barros Leite, José Ignácio do Rosário, Sebastião da Silva, José Leite Cordeiro, Filena Veiga dos Santos, José da Silva, Antonio de Souza, Manoel de Almeida, Antônio José de Almeida, Benedicto dos Santos Aguiar, Manoel Esteves dos Santos, Henrique Dias de Almeida e outros. In: Ficha de atividades político-sociais de Isaltino Veiga dos Santos, 09 de novembro de 1935. Prontuário no 2018, Isaltino Veiga dos Santos. DEOPS/SP, AESP. 
${ }^{14}$ Ficha de atividades político-sociais de Isaltino Veiga dos Santos. Prontuário no 2018, Isaltino Veiga dos Santos. DEOPS/SP, AESP.

${ }^{15}$ LEITE, José Correia. ...E disse o velho militante José Correia Leite: depoimentos e artigos. Organizado por Cuti. São Paulo: Secretaria Municipal da Cultura, 1992, p. 116.

${ }^{16}$ LEITE, José Correia e MOREIRA, Renato Jardim. Movimentos sociais no meio negro. São Paulo, mimeog, s/d, p. 28.

${ }^{17}$ LEVINE, Robert M. O regime de Vargas: os anos críticos (1934-1938). Trad. Raul de Sá Barbosa. Rio de Janeiro: Nova Fronteira, 1980, p. 161.

${ }^{18}$ LEVINE, Robert M. Pai dos pobres? O Brasil e a era Vargas. Trad. Anna de Barros Barreto. São Paulo: Companhia das Letras, 2001, p. 69.

${ }^{19}$ CARONE, Edgard, op. cit., p. 259.

${ }^{20}$ ROSE, R. S. Uma das coisas esquecidas: Getúlio Vargas e controle social no Brasil (19301954). São Paulo: Companhia das Letras, 2001, p. 86.

${ }^{21}$ CARONE, Edgard, op. cit., p. 262.

${ }^{22}$ SODRÉ, Nelson Werneck. História militar do Brasil. $3^{\underline{a}}$ ed., Rio de Janeiro: Civilização Brasileira, 1979, p. 260.

${ }^{23}$ ROSE, R. S., op. cit., p. 90.

${ }^{24}$ Carta de Isaltino Veiga dos Santos ao Ilmo. Snr. Dr. Armando Franco Soares Caiuby. São Paulo, 29 de janeiro de 1936. Prontuário no 2018, Isaltino Veiga dos Santos. DEOPS/SP, AESP.

${ }^{25}$ Declarações de Isaltino Veiga dos Santos ao M.M. Juiz Comissário para inquirição de presos políticos, Dr. Alexandre Delfino de Amorim Lima. São Paulo, 06 de dezembro de 1935. Prontuário no 2018, Isaltino Veiga dos Santos. DEOPS/SP, AESP.

${ }^{26}$ LEVINE, Robert M. O regime de Vargas: os anos críticos (1934-1938). Trad. Raul de Sá Barbosa. Rio de Janeiro: Nova Fronteira, 1980, p. 201; ROSE, R. S., op. cit., p. 126-131.

${ }^{27}$ Requerimento de Isaltino Veiga dos Santos ao Exmo. Snr. Dr. Egas Botelho. MD Superintendente da Ordem Política e Social. São Paulo, Presídio Político Maria Zélia, 17 de abril de 1936. Prontuário no 2018, Isaltino Veiga dos Santos. DEOPS/SP, AESP.

${ }^{28}$ Requerimento de Isaltino Veiga dos Santos ao Exmo. Snr. Dr. Egas Botelho. MD Superintendente da Ordem Política e Social. São Paulo, Presídio Político Maria Zélia, 13 de maio de 1936. Prontuário no 2018, Isaltino Veiga dos Santos. DEOPS/SP, AESP.

${ }^{29}$ Requerimento de Isaltino Veiga dos Santos ao Exmo. Snr. Dr. Egas Botelho, M. D. Superintendente da Ordem Política e Social. São Paulo, 15 de maio de 1936. Prontuário no 2018, Isaltino Veiga dos Santos. DEOPS/SP, AESP.

${ }^{30}$ Requerimento de Filena Veiga dos Santos ao Exmo. Snr. Dr. Arthur Leite de Barros, M. D. Secretário da Segurança Pública. São Paulo, fevereiro de 1936. Prontuário no 2018, Isaltino Veiga dos Santos. DEOPS/SP, AESP.

${ }^{31}$ Relatório de João Agostinho ao Ilmo. Snr. Dr. Egas Botelho, Superintendente de Ordem Política e Social. 13 de março de 1936. Prontuário no 2018, Isaltino Veiga dos Santos. DEOPS/SP, AESP. 
32 Carta de Arlindo Veiga dos Santos ao Exmo. Sr. Dr. Egas Botelho, Superintendente da Ordem Política e Social. São Paulo, 20 de julho de 1936. Prontuário no 2018, Isaltino Veiga dos Santos. DEOPS/SP, AESP.

33 Ofício de Isaltino Veiga dos Santos, Secretário Geral da Frente Negra Brasileira, ao Exmo. Snr. Dr. Armando Soares Caiuby, D. P. Delegado de Ordem Política Social. 01 de junho de 1933. Prontuário no 1538, Frente Negra Brasileira. DEOPS/SP, AESP.

${ }^{34}$ Diário da Noite. São Paulo, 27 de janeiro de 1932.

${ }^{35}$ A Voz da Raça. São Paulo, 13 de maio de 1933, p. 1.

${ }^{36}$ Carta de Isaltino Veiga dos Santos ao Ilmo. Snr. Dr. Armando Franco Soares Caiuby. São Paulo, 29 de janeiro de 1936. Prontuário no 2018, Isaltino Veiga dos Santos. DEOPS/SP, AESP.

${ }^{37}$ Em carta enviada para um "amigo", Isaltino V. dos Santos dava explicação semelhante: "Desconfiando como sempre desconfiei, de todas as organizações que aparecem em $S$. Paulo, geralmente para arrastar os elementos de minha raça a competições inglórias e impatrióticas e, por isso mesmo, contraproducentes como soe sempre acontecer, resolvi assinar o manifesto da Frente Popular pela Liberdade, pois que só assim poderia eu merecer a confiança daqueles que a formaram e assim obter esclarecimentos do que lá se trataria, para na ocasião oportuna desmascarar os trabalhadores da pátria, pois que a meu ver, aquilo nada mais era do que a continuação da Aliança Nacional Libertadora”. Prontuário no 2018, Isaltino Veiga dos Santos. DEOPS/SP, AESP.

${ }^{38}$ Ficha de atividades político-sociais de Isaltino Veiga dos Santos, 06 de outubro de 1936. Prontuário no 2018, Isaltino Veiga dos Santos. DEOPS/SP, AESP.

${ }^{39}$ De fato, Isaltino Veiga dos Santos procurou colaborar com as autoridades policiais no presídio, chegando mesmo a delatar um plano de fuga dos presos políticos. Ofício do Diretor do Presídio Político da Capital, Plínio de Souza Moraes, ao Ilmo. Snr. Dr. Superintendente de Ordem Política e Social da Capital. São Paulo, 02 de fevereiro de 1937. Prontuário no 2018, Isaltino Veiga dos Santos. DEOPS/SP, AESP.

${ }^{40}$ Carta de Isaltino Veiga dos Santos ao Ilmo. Snr. Dr. Armando Franco Soares Caiuby. São Paulo, 29 de janeiro de 1936. Prontuário no 2018, Isaltino Veiga dos Santos. DEOPS/ SP, AESP. José Correia Leite confirma que Isaltino Veiga dos Santos, quando preso no presídio Maria Zélia, "pôs a boca no trombone, dizendo nunca ter sido comunista. Os comunistas que estavam no mesmo cárcere quiseram bater nele. Foi preciso transferir o Isaltino para uma cela solitária senão acabavam até matando ele”. LEITE, José Correia, op. cit., p. 116.

${ }^{41}$ Ofício de Armando Caiuby a Egas Botelho. São Paulo, 31 de janeiro de 1936. Prontuário no 2018, Isaltino Veiga dos Santos. DEOPS/SP, AESP.

${ }^{42}$ ROSE, R. S., op. cit., p. 137.

${ }^{43}$ Relatório do investigador Elpídio Gomes ao Ilmo. Snr. Dr. Delegado de Ordem Política, 10 de abril de 1937. Prontuário no 2018, Isaltino Veiga dos Santos. DEOPS/SP, AESP.

${ }^{44}$ CANCELLI, Elizabeth. O mundo da violência: a polícia da era Vargas. $2^{\underline{a}}$ ed., Brasília: Editora da Universidade de Brasília, 1994, p. 80.

TOPOI, v. 8, n. 14, jan.-jun. 2007, pp. 146-171. 


\section{Referências bibliográficas}

AGGIO, Alberto e BARBOSA, Agnaldo de Sousa e COELHO, Hercídia Mara Facuri. Politica e sociedade no Brasil (1930-1964). São Paulo: Annablume, 2002. ANDREWS, George Reid. Negros e brancos em São Paulo (1888-1988). Trad. Magda Lopes. Bauru-SP: Edusc,1998.

. O protesto político negro em São Paulo (1888-1988). Estudos Afro-Asiáticos, n. 21, pp. 27-48, 1991.

BARCELOS, Luiz Cláudio. Mobilização racial no Brasil: uma revisão crítica. Afro-Asia, n. 17, pp. 187-210, 1996.

BASTIDE, Roger e FERNANDES, Florestan. Brancos e negros em São Paulo. $2^{a}$ ed., São Paulo: Ed. Nacional, 1959.

BICUDO, Virgínia Leone. Estudo de atitudes raciais de pretos e mulatos em São Paulo. Tese de mestrado apresentada à Escola Livre de Sociologia e Política de São Paulo. São Paulo, 1945.

BUTLER, Kim D. Freedoms given, freedoms won: afro-brazilians in post-abolition. São Paulo and Salvador. New Brunswick, NJ: Rutgers University Press, 1998.

CANCELLI, Elizabeth. $O$ mundo da violência: a polícia da era Vargas. $2^{\underline{a}}$ ed., Brasília: Editora da Universidade de Brasília, 1994.

CARDOSO, Paulino de Jesus Francisco. A luta contra a apatia: estudo sobre a instituição do movimento negro anti-racista na cidade de São Paulo (1915-1931). Dissertação de mestrado apresentado ao Programa de Pós-Graduação em História da PUC. São Paulo, 1993.

CARNEIRO, Maria Luiza Tucci. O anti-semitismo na era Vargas: fantasmas de uma geração (1930-1945). São Paulo: Brasiliense, 1988.

CARONE, Edgard. A República Nova (1930-1937). 2ª ed., São Paulo: Difel, 1976.

lo: Ática, 1989.

Revoluçôes do Brasil contemporâneo (1922-1938). $4^{\mathrm{a}}$ ed., São Pau-

DOMINGUES, Petrônio. Uma história não contada: negro, racismo e branqueamento em São Paulo no pós-abolição. São Paulo: Ed. Senac, 2004.

. Frente Negra Brasileira (1931-1937) e a luta contra o racismo no

Brasil. Revista Histórica, n. 14, pp. 15-18, $2004 a$.

Paladinos da liberdade: a experiência do Clube Negro de Cultura

Social (1932-1938). Revista de História, n. 150, pp. 57-79, $2004 \mathrm{~b}$. 
. A insurgência de ébano. A história da Frente Negra Brasileira (19311937). Tese de doutorado apresentada ao Programa de Pós-Graduação em História Social da USP. São Paulo, 2005.

FERNANDES, Florestan. A integração do negro na sociedade de classes. $3^{a}$ ed., São Paulo: Ática, 1978.

. O negro no mundo dos brancos. São Paulo: Difel, 1972.

HERNANDEZ, Leila Maria Gonçalves. Aliança Nacional Libertadora: ideologia e ação. Porto Alegre: Mercado Aberto, 1985.

LEITE, José Correia. ...E disse o velho militante José Correia Leite: depoimentos e artigos. Organizado por Cuti. São Paulo: Secretaria Municipal da Cultura, 1992.

LEITE, José Correia e MOREIRA, Renato Jardim. Movimentos sociais no meio negro. São Paulo, mimeog, s/d.

LEVINE, Robert M. O regime de Vargas: os anos criticos (1934-1938). Trad. Raul de Sá Barbosa. Rio de Janeiro: Nova Fronteira, 1980.

. Pai dos pobres? O Brasil e a era Vargas. Trad. Anna de Barros Barreto.

São Paulo: Companhia das Letras, 2001.

LOWRIE, Samuel. O elemento negro na população de São Paulo. Revista do Arquivo Municipal. São Paulo, v. 48, pp. 5-56, 1938.

MITCHELL, Michael. Racial consciousness and the political attitudes and behavior of blacks in São Paulo, Brazil. Dissertação de Ph.D. apresentada ao Programa de Pós-Graduação da Universidade de Indiana. Indiana, 1977.

MOURA, Clóvis. O negro, de bom escravo a mau cidadão? Rio de Janeiro: Conquista, 1977.

. Organizações negras. In: SINGER, Paulo e BRANT, Vinicius Caldeira (Orgs). São Paulo: o povo em movimento. Petrópolis/RJ, Vozes/CEBRAP, 1980, pp. 143-175.

. Brasil: as raizes do protesto negro. São Paulo: Global, 1983.

. As Injustiças de Clio. O negro na historiografia brasileira. Belo Horizonte: Oficina de Livros, 1990.

PINTO, Regina Pahim. O movimento negro em São Paulo: luta e identidade. Tese de doutorado apresentada ao Programa de Pós-Graduação em Antropologia da USP. São Paulo, 1993.

ROSE, R. S. Uma das coisas esquecidas: Getúlio Vargas e controle social no Brasil (1930-1954). São Paulo: Companhia das Letras, 2001. 
SILVA, José Carlos Gomes da. Os suburbanos e a outra face da cidade. Negros em São Paulo (1900-1930): cotidiano, lazer e cidadania. Dissertação de mestrado apresentada ao Programa de Pós-Graduação em Antropologia da Unicamp. Campinas, 1990. SODRÉ, Nelson Werneck. História militar do Brasil. $3^{2}$ ed., Rio de Janeiro: Civilização Brasileira, 1979.

TRINDADE, Hélgio. Integralismo: o fascismo brasileiro na década de 30. $2^{\underline{a}}$ ed., São Paulo-Rio de Janeiro: Difel, 1979.

\section{RESUMO}

A finalidade deste artigo é enfocar o drama vivido por Isaltino Veiga dos Santos (uma das principais lideranças do movimento negro brasileiro na década de 1930) no cárcere do governo Vargas. Apesar de preso pela Delegacia de Ordem Politica e Social (Deops) sob a acusação de realizar atividades subversivas, Veiga dos Santos negou veementemente ser comunista. Assim, a questão central a ser respondida aqui é: ele realmente era comunista ou houve algum tipo de engano por parte do órgão de repressão do governo Vargas?

Palavras-chave: negros, movimentos sociais, movimento negro, regime Vargas.

\section{ABSTRACT}

The aim of this article is to focus the drama lived by Isaltino Veiga dos Santos (one of the most important leaderships of the Brazilian black movement in the 1930's decade) in the prisons of Vargas's government. Besides being in jail in the Delegacia de Ordem Politica e Social (Deops) under the accusation of performing subversive activities, Veiga dos Santos strongly denied being communist. So, the central question to be answered here is: Was he really communist or had there been any kind of mistake coming from the repression organs of Vargas's government?

Keywords: black people, social movements, black movement, Vargas's political system.

(recebido em outubro de 2005 e aprovado em dezembro de 2006) 